\title{
ETHNOBOTANY OF THE PEANUT IN RECÔNCAVO DA BAHIA, BRAZIL
}

\author{
ETNOBOTÂNICA DO AMENDOIM NO RECÔNCAVO DA BAHIA, BRASIL
}

\author{
Ademir Trindade ALMEIDA ${ }^{1}$; Clovis Pereira PEIXOTO ${ }^{2}$; \\ Viviane Guzzo de Carli POELKING ${ }^{3}$; Luiz Fernando Melgaço BLOISI ${ }^{4}$; \\ Jamile Maria da Silva dos SANTOS ${ }^{5}$; Ana Maria Pereira Bispo dos SANTOS ${ }^{1}$
}

1. Doutorando(a) do Programa de Pós-Graduação em Ciências Agrárias, Universidade Federal do Recôncavo da Bahia - UFRB, Cruz das Almas. ademirtrindadeufrb@ hotmail.com; 2. Professor, Doutor, Centro de Ciências Agrárias, Ambientais e Biológicas - CCAAB UFRB, Cruz das Almas, BA, Brasil; 3. Pós-doutoranda CAPES - UFRB, Cruz das Almas, BA, Brasil; 4. Engenheiro Agrônomo, mestre em Recursos Genéticos Vegetais - UFRB - EMBRAPA, Cruz das Almas, BA, Brasil; 5. Engenheira Agrônoma, Doutora em Ciências Agrárias - UFRB, Cruz das Almas, BA, Brasil.

\begin{abstract}
The aim of this study was to perform an ethnobotanical survey in some regions of Recôncavo da Bahia, Brazil, to investigate the profile of farmers and the local knowledge about Arachis hypogaea $\mathrm{L}$. (peanut). We sampled 60 local peanut farmers from rural areas in the municipalities Conceição do Almeida, Cruz das Almas, Maragogipe, São Felipe, São Félix, Sapeaçú and Lage. One producer per residence was interviewed and a semi-structured interview model was used. During the interviews, seeds stored by the producers were collected for future analysis. The frequency of the answers was calculated using SAS (Statistical analysis system) software. Using an ethnobotanical approach, we were able to show that peanut cultivation is part of the Recôncavo da Bahia culture and that farmers in the area have their own knowledge about the use and management of this crop. This knowledge arose from information passed down over the years from previous generations. Similar farming techniques were used in all of the studied municipalities.
\end{abstract}

KEYWORDS: Crops. Family farming. Interview. Local knowledge. Arachis hypogaea L.

\section{INTRODUCTION}

Ethnobotany is defined as the study of interrelationships between humans and plants (FORD, 1978). It is a method used to discover the different usage patterns of a plant species and assists in understanding the dynamics of knowledge of human groups, which are fundamental aspects when trying to conserve plant resources and local knowledge about them (MIRANDA; HANAZAKI, 2008).

Ethnobotanical studies evaluate how residents gather and use information from their places of origin compared to information obtained where they currently live. This approach also considers how residents incorporate new knowledge from different parts of Brazil, including new plants to cover their needs that will have to adapt to new environments (CUNHA; BORTOLOTTO, 2011). Therefore, Carniello et al. (2010) asserts that ethnobotany includes the study of the relationships established by human communities with plants.

Knowledge about the wide range of uses of plant species (either crops or plants with other purposes that are remarkable to human history) is important when obtaining information about the past that can contribute to the progress of a community or region. One way to acquire this information is by using an ethnobotanical study that analyzes the common knowledge about the use of plants, something that is often restricted to particular communities or regions (MARTINS et al., 2005). Furthermore, this tool can analyze gender relationships in agriculture (VIU et al., 2010).

In Brazil, ethnobotanical studies are conducted in a scenario of cultural and biological diversity that constitutes a valuable potential heritage, including plants of economic interest, which could stimulate the creation of new jobs and income, potentially in an environmentally sustainable way (OLIVEIRA et al., 2009).

Botanists became interested in the peanut (Arachis hypogaea L., mandu'wi in Tupi, which means "buried"), a dicotyledon in the Fabaceae, in the $18^{\text {th }}$ century when they began studying its morphological variation. These studies identified and classified wild species of Arachis native to Brazil, Paraguay, Argentina and Bolivia, including the discovery of new species (FERNANDEZ ; KRAPOVICKAS, 1994).

Arachis L. comprises 81 species distributed in nine taxonomic sections (KRAPOVICKAS; GREGORY, 1994), and includes several economically important species (grown for their fruits, for forage or as an ornamental). In addition, desirable characteristics can be transferred from wild to domesticated species (VALLS, 2005). 
Recôncavo is one of 27 territories in the state of Bahia, comprises 20 municipalities (SEI 2013), covers an area of 5,221,201 $\mathrm{km}^{2}$, and has a population of 576,672 inhabitants. Within the region, there are mostly small fields of crops managed by family farmers. The peanut, Arachis hypogaea $\mathrm{L}$., is the most commonly cultivated plant in the region and generates income for the producers mainly in June when there is a major celebration called Festa Junina (June's Festival). During the festival, many traditional peanut dishes are made, in addition to the high consumption of peanuts alone, which are cooked. In Brazil, $60 \%$ of peanut production is intended for the fresh market segment and 30\% for the confectionery segment (PEREIRA et al., 2008). The remaining percentage is related to other minor uses, including oil chemical production (FREITAS et al., 2005).

In northeastern Brazil, the technology used by farmers to grow peanuts is simple, which results in low levels of production even when farming large areas (ALMEIDA et al., 2014). These methods usually consist of manual techniques inherited from ancestors. For this reason, ethnobotany is an essential tool to better understand how information about peanuts was passed down throughout the years, which could increase the knowledge of the species.
Considering the significance of peanuts to Recôncavo da Bahia farmers, as well as the importance of acquiring information that will improve the knowledge of crop use and management, the aim of this study was to conduct an ethnobotanical survey in some towns of the region, focusing on the profile of the farmers and the characterization of the local knowledge about the species.

\section{MATERIAL AND METHODS}

The survey was conducted in the municipalities of Conceição do Almeida, Cruz das Almas, Maragogipe, São Felipe, São Felix and Sapeaçu, located in Recôncavo da Bahia, Brazil, and the city of Laje located on the border of this territory.

Recôncavo da Bahia is a geographical region located around Todos os Santos Bay, including the coastline and the region surrounding the inner bay (Figure 1), and comprises thirty-four cities, including the capital Salvador. The term Recôncavo is normally used in reference to the cities near Todos os Santos Bay, which are mostly rural.
(A)

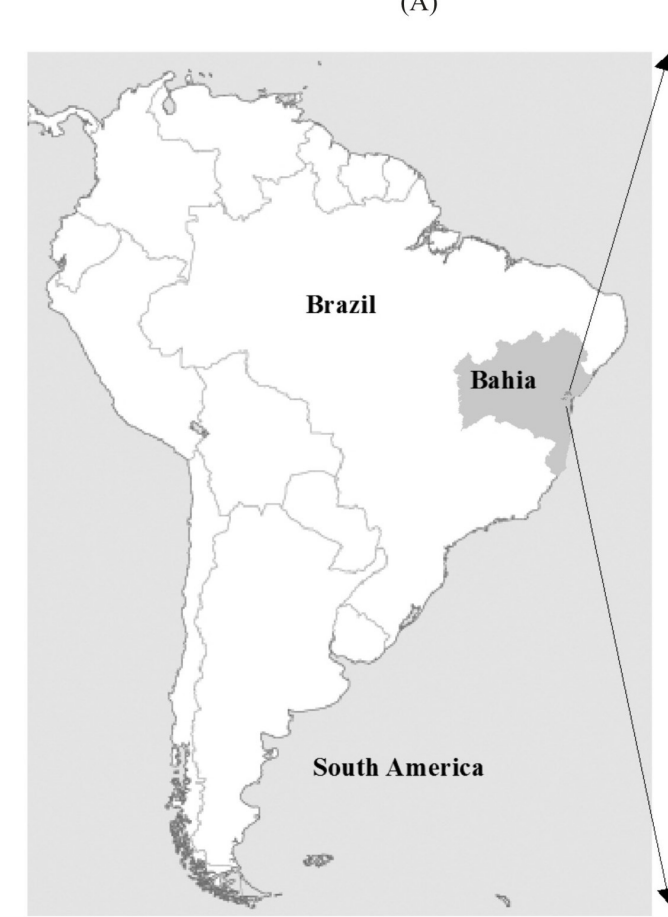

(B)

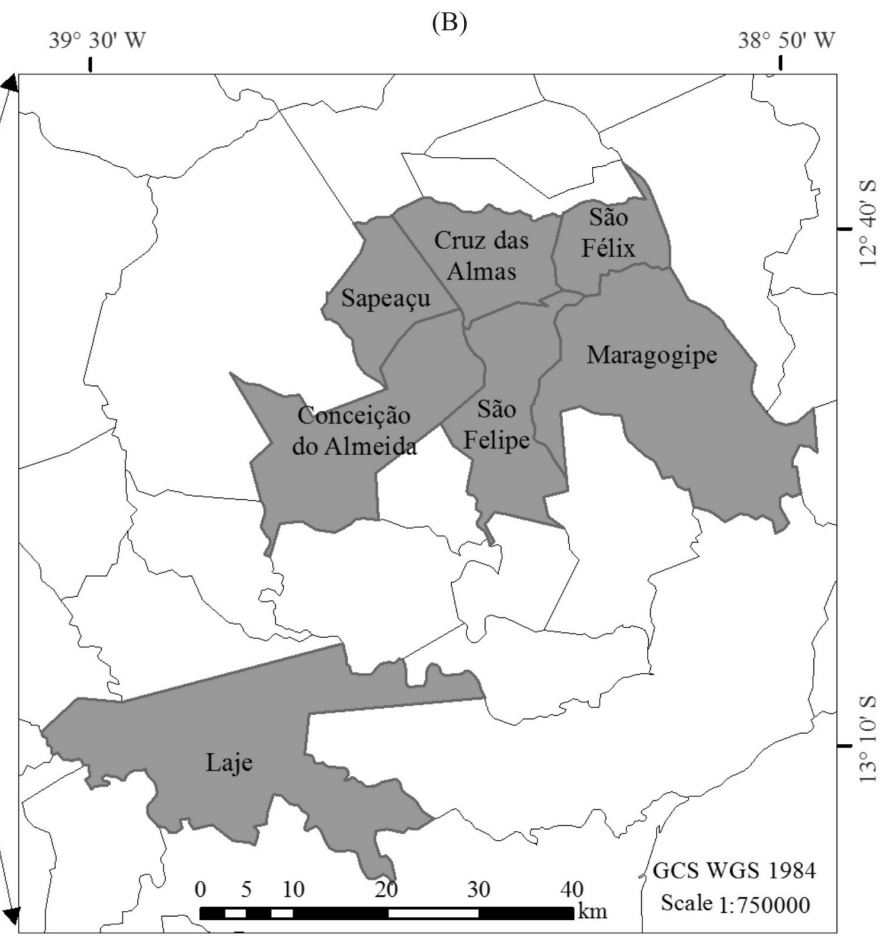

Figure 1. Map of the study area. A: South America, Brazil and Bahia. B: Recôncavo da Bahia counties (gray areas) where the genotypes were collected. 
The study area is considered the cradle of Brazilian agriculture because it was the first region where sugarcane was farmed for export. Cotton, coffee, tobacco and citrus are also farmed in the region, in addition to plantations of subsistence crops, such as corn, beans, cassava, yams, peanuts and significant areas of pasture (GONÇALVES et al., 2004). Furthermore, this area is considered an oil-rich region.

Visits to communities of peanut producers living in the rural areas were conducted from January to February 2012. One person per household was interviewed, for a total of 60 individuals. We used a semi-structured interview model with 45 objective and subjective questions.

To select the interviewees, the study area was visited and a resident known by the community and producers was chosen to follow the survey and play the role of mediator between the researcher and the interviewee.

The family profile of each farmer was generated based on gender, age, education level, and the ethnobotanical survey, which included information about usage, popular names, occurrence, planting methods, season, storage methods, marketing, farming practices, interplanting and size of the area of the peanut crop. During the interviews, seeds stored by farmers from previous harvests were collected. All participants signed a disclosure authorization based on provisional measure No. 2186-16 of August 23, 2001, giving them the right to access the results.
The data was tabulated according to the categories related to each question, while the percentage frequency was calculated according to the farmers' answers. Statistical analyses were performed using the program SAS - Statistical Analysis System.

\section{RESULTS AND DISCUSSION}

The results revealed that $43(72 \%)$ of the interviewed farmers were born in the town where they live today (Table 1), $16(26 \%)$ are from other locations of Recôncavo da Bahia, and one (2\%) is from another region of Bahia. Therefore, the information collected in this study is limited to the study region, and the result of knowledge acquired by local farmers throughout their lives.

Information related to the profiles of the surveyed interviewees revealed that the majority are males, between the ages of 36 and 60, married with children, and have a low degree of illiteracy, which shows a certain consistency between respondents, regardless of the municipality and community where the study was performed (Table 1).

The predominance of males interviewed in this study may be related to the fact that most of the interviewees are married and that field work requires a lot of physical effort. Furthermore, women are more responsible for housework and childcare. According to Viu et al. (2010), women have been responsible for housework and child care in many societies throughout history, renouncing field work.

Table 1. Questionnaire, category and frequency of responses of the ethnobotanical survey about the peanut crops produced by farmers from Recôncavo da Bahia.

\begin{tabular}{lcc}
\hline Questions & Category & Frequency (\%) \\
\hline \multirow{2}{*}{ What is your gender? } & Male & 86,67 \\
& Female & 13.33 \\
\hline \multirow{2}{*}{ Do you have children? } & Yes & 91.67 \\
& No & 833 \\
\hline \multirow{2}{*}{ What is your marriage status? } & Married & 11.33 \\
& Single & 5 \\
\hline & Widow/widower & 13.33 \\
& Illiterate & 46.67 \\
& Elementary education not completed & 15 \\
What is the highest degree you have completed? & Elementary education completed & 13.33 \\
& $1^{\text {st }}$ year secondary- incomplete & 3.33 \\
& $1^{\text {st }}$ year secondary- complete & 1.67 \\
& $2^{\text {nd }}$ year secondary- incomplete & 5 \\
& $2^{\text {2d }}$ year secondary -complete & 1.67 \\
\hline \multirow{2}{*}{ What is your occupation? } & Higher education- incomplete & 98.33 \\
& Farmer & 1.67 \\
\hline Where did you grow up? & Other & 96.67
\end{tabular}


Urban

Place of origin

How long have you lived in your current town?

What is the number of people living in your residence?

Do they work on the farm?
Is anyone retired?
Is anyone subsidized by the government?
Have you worked in a different place befo
What is the origin of the seeds collected?
What is the popular name of the variety?

Do you own or rent the land?

What is the size of cultivated area?

How many crops per year?

Do you use a weed control?

Do you use intercropping?

What part of the plant is used for commercialization?

Do you select plants?

Do you select seeds?

Do you keep seeds for planting?

Do all seeds germinate?

Do all seeds germinate at the same time?

Do they grow similarly?

Do you exchange seeds with other people?

Do you use fertilizers or manure?

What is the average productivity?

Same place where they work $\quad 72$

Another town in Recôncavo da Bahia 26 Another region of Bahia 2

More than 10 years 95

Less than 10 years 5

More than 5 people 20

Less than 5 people $\quad 70$

5 people

Yes 68.33

$\begin{array}{ll}\text { No } & 31.67\end{array}$

Yes 38.33

No $\quad 61.67$

Yes $\quad 58.33$

$\begin{array}{ll}\text { No } & 46.67\end{array}$

Yes 20

No 80

Crops 100

Spontaneous growth

0

91.67

8.33

$\begin{array}{cc}\text { Other } & 8.33 \\ \text { Own land } & 90\end{array}$

Rent

10

$\begin{array}{cc}\text { Over } 4356 \mathrm{~m}^{2} & 10 \\ \text { Below } 4356 \mathrm{~m}^{2} & 18.33 \\ & 51.67\end{array}$

$4356 \mathrm{~m}^{2}$ 30

Once per year $\quad 58.33$

More than once per year $\quad 41.67$

Once per crop cycle 65

Twice per crop cycle $\quad 35$

Yes $\quad 51.67$

No $\quad 48.33$

Legumes 100

Other 0

\begin{tabular}{cc} 
Yes & 6.67 \\
No & 93.33 \\
Yes & 71.67 \\
No & 28.33 \\
Yes & 100 \\
No & 0 \\
Yes & 100 \\
No & 0 \\
Yes & 100 \\
No & 0 \\
Yes & 98.33 \\
No & 1.67 \\
Yes & 3.33 \\
No & 96.67 \\
\hline Manure & 43.3 \\
Fertilizer & 16.7 \\
No & 40 \\
\hline ver 25,000 L & 31.67 \\
25,000 L & 63.33 \\
\hline
\end{tabular}




\begin{tabular}{lcc}
\hline Is there a demand for peanuts? & Yes & 100 \\
\multirow{2}{*}{ What is the use of farmed peanuts? } & No & 0 \\
& Commercialization & 100 \\
\multirow{2}{*}{ How are they commercialized? } & Other & 0 \\
\hline \multirow{2}{*}{ How long have you farmed peanuts? } & Sold to dealers & 85 \\
& Sold in town markets & 15 \\
\hline \multirow{2}{*}{ Is it a lucrative job? } & More than 10 years & 83.33 \\
& Less than 10 years & 3.33 \\
\multirow{2}{*}{ Do you receive technical assistance? } & 10 years & 13.33 \\
\hline \multirow{2}{*}{ Do you grow other crops? } & Yes & 93.33 \\
& No & 6.67 \\
\hline \multirow{2}{*}{ Do you plan to continue farming peanuts? } & Yes & 3.33 \\
& No & 96.67 \\
\hline \multirow{2}{*}{ Do pests or diseases affect your peanut crops? } & Yes & 96.67 \\
\end{tabular}

Contrary to what we found in this study, normally, a greater number of women participate in ethnobotanical studies. Most of these studies have investigated the use of plant species in crafts (SANTOS; COELHO-FERREIRA, 2012), urban backyards (CARNIELLO et al., 2010) and the use of medicinal species (PILLA et al., 2006; SILVA; PROENÇA, 2008; VIU et al., 2010; CUNHA; BORTOLOTTO, 2011; MEYER et al., 2012).

Interestingly, our study differs from most other ethnobotanical works. This study found that peanuts are mainly grown for commercialization for both fresh consumption and for food industries, especially the confectionery industry (PEREIRA et al., 2008). The results also show that the sixty farmers interviewed obtain peanuts from crops and not from spontaneous vegetation, as is the case for most herbal medicines.

Even though a low education level is still a reality in rural areas of Brazil, especially among small farmers, a low illiteracy rate was found in this study (Tab. 1). It is interesting to highlight that $86.67 \%$ of the interviewed people started elementary school, which explains the low rate, even for people who consider farming as their main occupation.

In a similar study about medicinal species, Meyer et al. (2012) also found a low rate of illiteracy. However, Carniello et al. (2010), in the region of Mirassol D'Oeste (Mato Grosso), and Pinto et al. (2006), in rural communities at Itacaré (Bahia), found illiteracy rates of $31 \%$ and $42 \%$, respectively.

In relation to agriculture, about $80 \%$ of interviewed people have never performed another kind of activity. Almost all of the interviewed farmers (96.67\%) live in rural areas, and $80 \%$ live with up to five people in their residence. According to the survey, $31.67 \%$ of the people who live in the same residence as the farmers work in areas not related to agriculture. Usually, younger residents are the ones that seek jobs in nearby cities. In a rural community of Santa Barbara (Santa Catarina), Meyer et al. (2012) observed that the young population sought other sources of income, mostly in the textile industry. This and other factors, such as the presence of retirees in the family and/or assistance from the government, end up being additional income for farmers in the region.

Only $10 \%$ of the surveyed respondents do not own property, which has led them to lease land. The method of payment varies depending on the agreement with the landlord. Some farmers share their profit with the owner of the land, others divide it into three parts with a partner, who gets one third of the profit (depending on who is bearing the costs), and in some cases the owner leases the land for years or months for a preestablished amount. The reality of farmers in Rencôncavo da Bahia is different from that found by Baldalf et al. (2007), who recorded a more balanced distribution of the harvest of leather leaf fern in the municipality of Maquiné (Rio Grande do Sul), with $36.7 \%$ of respondents harvesting exclusively from their own land, $36.7 \%$ from leased land, and $26.6 \%$ from both.

At least $96.67 \%$ of the surveyed respondents cultivate other crops, such as cassava, yams, and citrus. Planting peanuts in the studied area is considered a good alternative as supplementary 
income, especially during June's Festival, when most of the annual crop is harvested in the region.

Over $80 \%$ of respondents have farmed peanuts for over ten years and all of them store seeds to use for subsequent planting. These have excellent rates of germination and emergence, which is the result of selecting the best seeds after harvesting, a method adopted by $71.67 \%$ of the interviewees.

The farmers harvest most of the production area to sell as fresh legumes, leaving a small production area to be harvested when the peanuts start to ripen, so they can be naturally dried in the sun. Selecting the legumes is done visually. The most uniform fruits, without smooth irregularities and preferably with three to four seeds, are selected. Afterwards, the seeds are stored and subsequently planted.

A small number of interviewees $(6.67 \%)$ stated that selection is performed in the field by separating blocks or bands of high performing plants that are collected, dried and stored (the same way described above) when they reach full maturity. However, this type of selection happens in an arbitrary way because a peanut plant that looks healthy is not always productive, considering that the legumes of the species grow below the soil surface, which makes selection harder.

The farmers interviewed reported excellent rates of germination and emergence, with satisfactory development that results in productive crops within the limits of the region. This could be attributed to the farming practices adopted by the producers during cultivation and post-harvest. Thus, we can infer that acquired knowledge is important to the cultivation of peanuts in Recôncavo da Bahia.

According to Lyra et al. (2011), the tradition of storing seeds by Brazilian rural families on their properties, which leads to an increase in seeds over the years, has become a good alternative for preserving agricultural diversity through farm conservation.

In northeastern Brazil, farmers prefer to grow peanuts that belong to the Valência Group (Arachis hypogaea var. fastigiata), the same group that the cultivar 'Vagem Lisa' is placed in, which is widely used in Recôncavo da Bahia. The species that belong to this group show favorable characteristics for the region, such as an erect habit, short cycle, reddish seeds, good adaptability to dry climate conditions, easy management, easy to manually harvest, in addition to being the most cited for raw consumption (SANTOS et al. 1997; ALVAREZ et al., 2005; PEIXOTO et al., 2008). A total of $91.67 \%$ of the producers that participated in this research grow 'Vagem Lisa' because of these characteristics. They argued that this cultivar produces more uniform seeds that leads to higher yields, higher quality and, consequently, higher profits.

Due to the fact that the technological level used in this region is low, most of the farmers prefer to cultivate 'Vagem Lisa' because the erect habit makes it easier to manually harvest the plants. Moreover, this cultivar dominates the region because it can be harvested before completely maturing, a peculiar feature of the Valencia Group. Thus, the legumes can be sold for fresh consumption.

A few farmers (3.33\%) exchange seeds with other producers. One of them explained that the reason for exchanging seeds was that the yield improved significantly when he used seeds of 'Maranhão.' Another interviewee, emphasized that 'Vagem Lisa' presents larger and more uniform legumes, which results in higher yields.

'Maranhão' belongs to the Valencia Group, which according to the farmers is used in the region because it resembles 'Vagem Lisa.' However, it has smaller seeds and the legume is longer. Thus, some producers that want to sell peanuts for fresh consumption are using this cultivar. There is also the so-called 'Miúdo' peanut, named by farmers in the region and usually cultivated by those that can not afford to buy 'Vagem Lisa' seeds.

All the interviewed farmers weed manually at least once during the crop cycle. Most of the farmers apply fertilizer (non-organic or organic) and prepare the soil before sowing, primarily by clearing or plowing and then harrowing the land. Some, after cleaning, directly sow the seeds in pits of approximately $20 \times 20 \mathrm{~cm}$.

Fertilizer is usually added before planting using manure from livestock and poultry $(43.3 \%)$ or other fertilizers $(16.7 \%)$. This is performed without any criteria of application, leading to some kind of uniformity in the distribution of the materials.

The peanut yield in Recôncavo da Bahia greatly varies depending on the farming practices and techniques used, in addition to soil and climatic factors that directly affect crops. Taking into consideration that the fruiting of the species is hypogeal (i.e., the legumes grow underground), protecting the soil is even more important to obtain a higher yield and better quality legumes (FREIRE et al. 2007).

Peanuts in Recôncavo da Bahia are commercialized using a vessel that holds 25-30 liters of legumes. Most farmers (85\%) sell the 
peanuts to dealers (people who buy and sell) on their properties.

According to the study, $68.33 \%$ of the surveyed respondents harvest a volume of legumes equal to or below 2500-3000 L per harvest (Fig. $2 \mathrm{~A}$ ), with $81.67 \%$ using an area equal to or smaller than a $4356 \mathrm{~m}^{2}$ (Figure 2B). The total area of land for the farmers that participated in the study was 24.64 hectares, where approximately $141,300 \mathrm{~L}$ of legumes were collected in the last harvest. Considering these data, the farmers produce 57346880 liters per hectare, from a population of 250,000 plants per hectare in spaced pits, as previously mentioned.
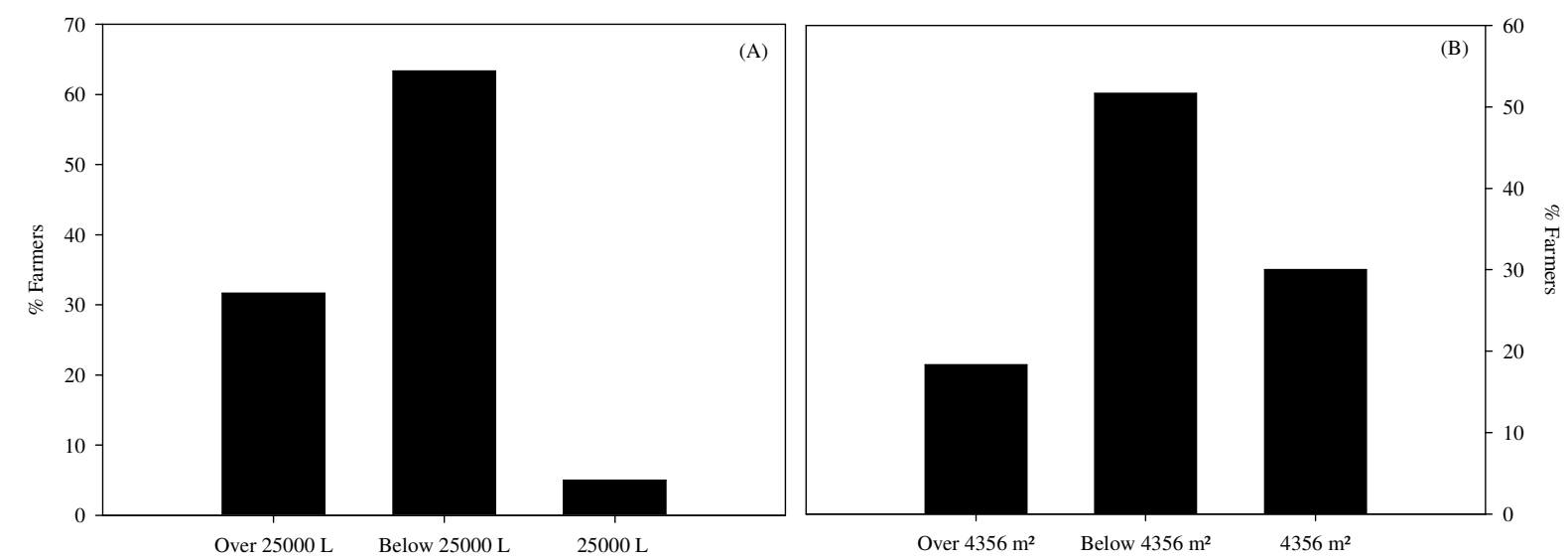

Figure 2. Average productivity (A) and size of cultivated area (B) used by farmers in an ethnobotanical survey of the peanut crop in Recôncavo da Bahia.

Gonçalves et al. (2004) studied different spatial arrangements where productivity reached 7,900 liters per hectare of fresh legumes using 232,500 plants per hectare, in the same conditions as those in Recôncavo da Bahia, which is superior to the productivity achieved by farmers in the present study. The unevenness of farm practices used can cause differences in productivity. According to Peixoto et al. (2008), farmers from Recôncavo da Bahia use production systems that are far from modern exploitation methods, working predominantly in small areas, using irregularly spaced pits made with hoes, and planting during the rainiest months. Due to these and other factors, Bahia has very low productivity compared to other states that grow this crop.

Intercropping might also generate low peanut productivity for farmers in Recôncavo da Bahia; however, only $51.67 \%$ practice this. In most cases, intercropping is done with citrus, until the citrus plants become large and start to take advantage of the peanut plants. This practice is also used with corn and yams, resulting in a considerable reduction of area exploited by peanut plants. On the other hand, the practice characterizes the farming system in Recôncavo da Bahia.

Pests and diseases also influence the low productivity of the plants, since $83.33 \%$ of the farmers confirmed frequent attacks by various caterpillars, ants and Lulus sabulosus cilindroiulus, in addition to some late season diseases (gray leaf spot and Fusarium). Thus, it is necessary to invest in technical assistance in these areas, in order to raise awareness among the farmers about the importance of good management practices for their crops. In addition to the cultural importance in the region, the peanut, a species that is somehow part of the history of family farmers, is a source of supplementary income. However, in addition to the knowledge accumulated by the farmers, there is a need of employing new technologies in crop management, in order to reach higher yields.

\section{CONCLUSIONS}

The peanut is part of the culture of Recôncavo da Bahia farmers. This species is one of the most important in the region, especially in June when consumption increases significantly due to demand during festivals. In addition, farmers hold personal knowledge about crop management, as a result of information passed down over generations.

Cultivation techniques are similar in all municipalities where the research was conducted. Sowing in irregularly spaced pits is considered an old technique that is still used today. The methods of weeding and harvesting used during and at the end of the crop cycle, respectively, are also 
performed manually, which are tedious tasks that often do not translate into compensatory profits.

In the region of Recôncavo da Bahia, the most common peanut type grown is 'Vagem Lisa' (of the Valencia Group) because its characteristics meet the preference of people who prefer to consume the peanuts raw.

\section{ACKNOWLEDGMENTS}

This study received financial support from the Coordenação de Aperfeiçoamento de Pessoal de Nível Superior (CAPES, Office for the Advancement of Higher Education).

RESUMO: Objetivou-se realizar um levantamento etnobotânico em alguns municípios do Recôncavo da Bahia visando uma investigação sobre o perfil dos agricultores, além da caracterização do conhecimento local sobre a espécie. Foram feitas visitas a 60 produtores residentes em comunidades da zona rural dos municípios de Conceição do Almeida, Cruz das Almas, Maragogipe, São Felipe, São Félix, Sapeaçú e Lage, que têm contato direto com a cultura do amendoim, sendo entrevistada uma pessoa por domicílio, e que cultiva o amendoim. Utilizou-se um modelo de entrevista semiestruturada. No momento das entrevistas, foram realizadas as coletas de sementes armazenadas pelos produtores para serem testadas em trabalhos futuros. Foi calculada a frequência percentual de acordo com as respostas dos agricultores com auxílio do programa estatístico SAS - Statistical Analysis System. Por meio do levantamento etnobotânico, fica claro que o amendoim faz parte da cultura do Recôncavo da Bahia e que os agricultores detêm conhecimentos próprios sobre as formas de uso e manejo da cultura, oriundos de informações repassadas ao longo dos anos, vindas de gerações anteriores, levando-os a utilizarem técnicas de cultivo parecidas em todos os municípios que contribuíram com a pesquisa.

PALAVRAS-CHAVE: Cultivos. Agricultura familiar. Entrevista. Conhecimento local. Arachis hypogaea L.

\section{REFERENCES}

ALMEIDA, T. A.; PEIXOTO, C. P.; BLOISI, L. F. M.; OLIVEIRA, J. S.; POELKING, V. G. C. Avaliação morfológica e produtiva de amendoim produzido por pequenos agricultores do Recôncavo da Bahia. Revista Caatinga, Mossoró, v. 27, n. 3, p. 150-159, 2014. http://www.redalyc.org/articulo.oa?id=237132104017

ALVAREZ, R. C. F.; RODRIGUES, J. D.; MARUBAYASHI, O. M.; ALVAREZ, A. C. C.; CRUSCIOL, C. A. C. Análise de crescimento de duas cultivares de amendoim (Arachis hypogaea L.). Acta Scientiarum.

Biological Sciences, Maringá, v. 27, n. 4, p. 611-616, 2005.

http://periodicos.uem.br/ojs/index.php/ActaSciAgron/article/view/1700/1095

BALDAUF, C.; HANAZAKI, N.; REIS, M. S. Caracterização etnobotânica dos sistemas de manejo de samambaia-preta (Rumohra adiantiformis (G. Forst) Ching - Dryopteridaceae) utilizados no sul do Brasil. Acta Botanica Brasilica, Feira de Santana, v. 21, n. 4, p. 823-834, 2007.

http://www.scielo.br/scielo.php?script=sci_arttext\&pid=S0102-33062007000400007.

https://doi.org/10.1590/S0102-33062007000400007

CARNIELLO, M. A.; SILVA, R. S.; CRUZ, M. A. B.; GUARIN NETO, G. Quintais urbanos de Mirassol D’Oeste-MT, Brasil: uma abordagem etnobotânica. Acta Amazônica, Manaus, v. 40, n. 3, p. 451-470, 2010. http://www.scielo.br/scielo.php?script=sci_arttext\&pid=S0044-59672010000300005.

https://doi.org/10.1590/s0044-59672010000300005

CUNHA, S. A.; BORTOLOTTO, I. M. Etnobotânica de plantas medicinais no assentamento monjolinho, município de anastácio, mato grosso do sul, Brasil. Acta Botanica Brasilica, Feira de Santana, v. 25, n. 3, p. 713-726, 2011. http://www.scielo.br/scielo.php?script=sci_arttext\&pid=S0102-33062011000300022. https://doi.org/10.1590/s0102-33062011000300022

FERNÁNDEZ, A; KRAPOVICKAS, A. Cromosomas y evolúcion en Arachis (Leguminosae). Bonplandia, Corrientes, v.8, p. 187-220, 1994. http://www.jstor.org/stable/41941178?seq=1\#page_scan_tab_contents 
FORD, R. I. Ethnobotany: historical diversity and synthesis. In: FORD, R. I. (Ed.) The nature and status of ethnobotany. Annals of Arnold Arboretum. Museum of Anthropology, University of Michigan, Michigan. Anthropological Papers, 1978. p: 33-49.

FREIRE, M. L. F.; BELTRÃO, N. E. M.; RAO, T. V. R.; MENEZES, H. E. A. Análise de crescimento nãodestrutiva do amendoinzeiro submetido a doses de $\mathrm{CaSO}_{4}$ e $\mathrm{P}_{2} \mathrm{O}_{5}$. Revista Brasileira de Ciências Agrárias, Recife, v. 2, n. 3, p. 193-199, 2007.

http://www.agraria.pro.br/sistema/index.php?journal=agraria\&page=article \&op=viewArticle\&path $\% 5 \mathrm{~B} \% 5 \mathrm{D}=1$ 09

FREITAS, M. S; MARTINS, S. S.; NOMI, K.; CAMPOS, A. F. Evolução do mercado brasileiro de amendoim. In: SANTOS, R. C. O agronegócio do amendoim no Brasil. Campina Grande: Embrapa Algodão; Brasília: Embrapa Informação Tecnológica, p. 15-44, 2005.

GONÇALVES, J. A.; PEIXOTO, C. A.; LEDO, C. A. S.; PEIXOTO, M. F. S. P.; SAMPAIO, H. S. V.; SAMPAIO, L. S. V.; ALMEIDA, N. S. Componentes de produção e rendimento de amendoim em diferentes arranjos espaciais no recôncavo Baiano. Revista Brasileira de Oleaginosas e Fibrosas, Campina Grande, v. 8, n. 2, p. 801-812, 2004.

KRAPOVICKAS, A.; GREGORY, W.C. Taxonomía del género Arachis (Leguminosae). Bonplandia v. 8, p. 1-186, 1994. http://ibone.unne.edu.ar/objetos/up/documentos/bonplandia/public/8_1_4/1_186.pdf

LYRA, D. H.; SAMPAIO, L. S.; PEREIRA, D. A.; AMARAL. C. L. F. Conservação on farm da agrobiodiversidade de sítios familiares em Jequié, Bahia, Brasil. evista Ceres, Viçosa, v. 58, n. 1, p. 69-76, 2011.

http://www.scielo.br/scielo.php?pid=S0034-737X2011000100011\&script=sci_abstract\&tlng=pt

MARTINS, A. G.; ROSÁRIO, D. L.; BARROS, M. N.; JARDIM, M. A. G. Levantamento etnobotânico de plantas medicinais, alimentares e tóxicas da Ilha do Combu, Município de Belém, Estado do Pará, Brasil.

Revista Brasileira de Farmatologia, Belém, v. 86, n. 1, p. 21-30, 2005.

http://www.rbfarma.org.br/files/pag_21a30_RBF86_1_2005_LEVANTAMENTO.pdf

MEYER, L.; QUADROS, K. E.; ZENI, A. L. B. Etnobotânica na comunidade de Santa Bárbara, Ascurra, Santa Catarina, Brasil. Revista Brasileira de Biociências, Porto Alegre, v. 10, n. 3, p. 258-266, 2012.

http://www.ufrgs.br/seerbio/ojs/index.php/rbb/article/view/1651

MIRANDA, T. M.; HANAZAKI, N. Conhecimento e uso de recursos vegetais de restinga por comunidades das ilhas do Cardoso (SP) e de Santa Catarina (SC), Brasil. Acta Botanica Brasilica, Feira de Santana, v. 22, n. 1, p. 203-215, 2008. http://www.scielo.br/scielo.php?pid=S0102-

33062008000100020\&script=sci_abstract\&tlng=pt. https://doi.org/10.1590/S0102-33062008000100020

OLIVEIRA, F. C.; ALBUQUERQUE, U. P.; FONSECA-KRUEL, V. S.; HANAZAKI, N. Avanços nas pesquisas etnobotânicas no Brasil. Acta Botânica Brasilica, Feira de Santana, v. 23, n. 2, p. 590-605, 2009. http://www.scielo.br/pdf/abb/v23n2/v23n2a31.pdf. https://doi.org/10.1590/S0102-33062009000200031

PEIXOTO, C. P.; GONÇALVES, J. A.; PEIXOTO, M. F. S. P.; CARMO, D. O. Características agronômicas e produtividade de amendoim em diferentes espaçamentos e épocas de semeadura no recôncavo Baiano.

Bragantia, Campinas, v. 67, n. 3, p. 563-568, 2008.

http://www.scielo.br/scielo.php?script=sci_arttext\&pid=S0006-87052008000300016

PEREIRA, J. W. L.; MELO FILHO, P. A.; SILVA, F. A. C.; SANTOS, R. C. Variabilidade genética de acessos de amendoim do tipo runner com base em marcadores RAPD. Revista Brasileira de Oleaginosas e Fibrosas, Campina Grande, v. 12, n. 1, p. 35-40, 2008. https://www.embrapa.br/busca-de-publicacoes//publicacao/278117/variabilidade-genetica-de-acessos-de-amendoim-do-tipo-runner-com-base-em-marcadoresrapd 
PILLA, M. A. C.; AMOROZO, M. C. M.; FURLAN, A. Obtenção e uso das plantas medicinais no distrito de Martim Francisco, Município de Mogi-Mirim, SP, Brasil. Acta Botanica Brasilica, Feira de Santana, v. 20, n. 4, p. 789-802, 2006. http://www.scielo.br/pdf/abb/v20n4/05.pdf. https://doi.org/10.1590/S010233062006000400005

PINTO, E. P. P.; AMOROZO, M. C. M.; FURLAN, A. Conhecimento popular sobre plantas medicinais em comunidades rurais de mata atlântica - Itacaré, BA, Brasil. Acta Botanica Brasilica, Feira de Santana, v. 20, n. 4, p. 751-762, 2006. http://www.scielo.br/scielo.php?script=sci_arttext\&pid=S0102-33062006000400001. https://doi.org/10.1590/S0102-33062006000400001

SANTOS, R. C.; MELO FILHO, P. A.; BRITO, S. F. M.; MORAES, J. S. Fenologia de genótipos de amendoim dos tipos botânicos Valência e Virgínia. Pesquisa Agropecuária Brasileira, Brasília, v. 32, n. 6, p. 607-612, 1997. https://seer.sct.embrapa.br/index.php/pab/article/view/4684

SANTOS, R. S.; COELHO-FERREIRA, M. Estudo etnobotânico de Mauritia flexuosa L. f. (Arecaceae) em comunidades ribeirinhas do Município de Abaetetuba, Pará, Brasil. Acta Amazônica, Manaus, v. 42, n. 1, p. 110, 2012. http://www.scielo.br/scielo.php?script=sci_arttext\&pid=S0044-59672012000100001.

https://doi.org/10.1590/S0044-59672012000100001

SEI (Superintendência de Estudos Econômicos e Sociais da Bahia). 2010. SIDE: Sistema de Dados

Estatísticos.http://www.sei.ba.gov.br/images/publicacoes/sumario/estatisticas_municipios/sumario_est_mun_v 4_reconcavo.pdf>.

SILVA, C. S. P.; PROENÇA, C. E. B. Uso e disponibilidade de recursos medicinais no município de Ouro Verde de Goiás, GO, Brasil. Acta Botanica Brasilica, Feira de Santana, v. 22, n. 2, p. 481-492, 2008. http://www.scielo.br/scielo.php?script=sci_arttext\&pid=S0102-33062008000200016. https://doi.org/10.1590/S0102-33062008000200016

VALLS, J. F. M. Recursos genéticos de Arachis: avanços no conhecimento botânico e a situação atual de conservação e uso. Agrociencia, v. 9, n. p. 123-132, 2005.

http://www.fagro.edu.uy/ agrociencia/index.php/directorio/article/view/286

VIU, A. F. M.; VIU, M. A. O.; CAMPOS, L. Z. O. Etnobotânica: uma questão de gênero? Revista Brasileira de Agroecologia, Porto Alegre, v. 5, n. 1, p. 138-147, 2010. http://www.abaagroecologia.org.br/revistas/index.php/rbagroecologia/article/view/9525 